\title{
Bi-phasic regulation of glycogen content in astrocytes via Cav-1/PTEN/AKT/GSK-3 pathway by fluoxetine
}

DOI:

10.1007/s00213-017-4547-3

\section{Document Version}

Accepted author manuscript

Link to publication record in Manchester Research Explorer

\section{Citation for published version (APA):}

Bai, Q., Song, D., Gu, L., Verkhratsky, A., \& Peng, L. (2017). Bi-phasic regulation of glycogen content in astrocytes via Cav-1/PTEN/AKT/GSK-3 pathway by fluoxetine. Psychopharmacology, 234(7), 1069-1077.

https://doi.org/10.1007/s00213-017-4547-3

\section{Published in:}

Psychopharmacology

\section{Citing this paper}

Please note that where the full-text provided on Manchester Research Explorer is the Author Accepted Manuscript or Proof version this may differ from the final Published version. If citing, it is advised that you check and use the publisher's definitive version.

\section{General rights}

Copyright and moral rights for the publications made accessible in the Research Explorer are retained by the authors and/or other copyright owners and it is a condition of accessing publications that users recognise and abide by the legal requirements associated with these rights.

\section{Takedown policy}

If you believe that this document breaches copyright please refer to the University of Manchester's Takedown Procedures [http://man.ac.uk/04Y6Bo] or contact uml.scholarlycommunications@manchester.ac.uk providing relevant details, so we can investigate your claim.

\section{OPEN ACCESS}




\section{Psycho- \\ pharmacology \\ Springer}

\section{Bi-phasic regulation of glycogen content in astrocytes via Cav-1/PTEN/AKT/GSK-3 $\beta$ pathway by fluoxetine}

\begin{tabular}{|r|l|}
\hline Journal: & Psychopharmacology \\
\hline Manuscript ID & Psych-2016-00546.R1 \\
\hline Manuscript Type: & Original Investigation \\
\hline Complete List of Authors: & $\begin{array}{l}\text { Bai, Qiufang; China Medical University } \\
\text { Song, Dan; China Medical University } \\
\text { Gu, Li; China Medical University } \\
\text { Verkhratsky, Alexej; The University of Manchester,; Ikerbasque } \\
\text { Peng, Liang; China Medical University, }\end{array}$ \\
\hline Keywords: & fluoxetine, Cav-1, PTEN, PI3K/AKT, GSK-3ß, glycogen \\
\hline & \multicolumn{2}{|l}{} \\
\hline
\end{tabular}

SCHOLARONE ${ }^{\text {Im }}$

Manuscripts 


\title{
Bi-phasic regulation of glycogen content in astrocytes via
}

\section{Cav-1/PTEN/AKT/GSK-3ß pathway by fluoxetine}

\author{
Qiufang Bai ${ }^{1}$, Dan Song ${ }^{1}, \mathrm{Li} \mathrm{Gu}^{1}$, Alexei Verkhratsky ${ }^{2,3}$ and Liang Peng ${ }^{1 *}$ \\ ${ }^{1}$ Laboratory of Metabolic Brain Diseases, Institute of Metabolic Disease Research and \\ Drug Development, China Medical University, Shenyang, P. R. China, ${ }^{2}$ Faculty of \\ Life Science, The University of Manchester, Manchester, UK; ${ }^{3}$ Achucarro Center for \\ Neuroscience, IKERBASQUE, Basque Foundation for Science, 48011 Bilbao, Spain
}

QB and DS contributed equally to this article.

*Corresponding author:

Professor Liang Peng, Laboratory of Brain Metabolic Diseases, Institute of Metabolic Disease Research and Drug Development, China Medical University, No. 77, Puhe Road, Shenbei District, Shenyang, P.R. China.

Phone: 86(24)23256666-5130;

Fax number: 86(24)23251769;

E-mail: hkkid08@yahoo.com

\section{Acknowledgements}

This study was supported by Grant No. 31400925 to DS from the National Natural Science Foundation of China.

\section{Conflict of interest}

The authors declare no conflict of interest. 


\begin{abstract}
Here we present the data indicating that chronic treatment with fluoxetine regulates Cav-1/PTEN/PI3K/AKT/GSK-3 $\beta$ signalling pathway and glycogen content in primary cultures of astrocytes with bi-phasic concentration dependence. At lower concentrations fluoxetine down-regulates gene expression of Cav-1, decreases membrane content of PTEN, increases activity of PI3K/AKT, and elevates GSK-3 $\beta$ phosphorylation thus suppressing its activity. At higher concentrations fluoxetine acts in an inverse fashion. As expected, fluoxetine at lower concentrations increased while at higher concentrations decreased glycogen content in astrocytes. Our findings indicate that bi-phasic regulation of glycogen content via Cav-1/PTEN/AKT/GSK-3 $\beta$ pathway by fluoxetine may be responsible for both therapeutic and side effects of the drug.
\end{abstract}

Key words: fluoxetine; Cav-1; PTEN; PI3K/AKT; GSK-3 $\beta$; glycogen 


\section{Introduction}

Astrocytes being homeostatic cells of the CNS (Verkhratsky and Butt 2013) are central elements for potassium ion $\left(\mathrm{K}^{+}\right)$buffering, for neurotransmitter homeostasis, for maintenance and regulation of synaptic transmission and for CNS metabolism. Astroglial contribution to major depression (similarly to other psychiatric pathologies - see Verkhratsky et al. 2014) does not involve astrogliosis and hypertrophy; rather the astrodegenerative signs prevail. The number of astrocytes, and expression of astrogliotic marker GFAP both are significantly decreased in the brains of depressed patients (McNally et al. 2008; Rajkowska et al. 2013). At the same time treatment with antidepressants increases GFAP levels (Barley et al. 2009). Expression of another astroglial marker, the calcium-binding protein $\mathrm{S} 100 \beta$ has been reduced in the ventral prefrontal cortex of depressed suicide victims (Klempan et al. 2009). Several other astroglial markers, such as aquaporin 4, astroglial connexins, astroglial plasmalemmal glutamate transporters and glutamine synthetase are all down-regulated in mood disorders (Rajkowska et al. 2013; Barley et al. 2009; Bernard et al. 2011; Sequeira et al. 2009). Reduced number of astrocytes and of their packing density was detected throughout the fronto-limbic areas of the brain, including the orbito-frontal area, and anterior cingulate, prefrontal, entorhinal and subgenual cortices, as well as the amygdala (Rajkowska et al. 2013; Verkhratsky et al. 2014; Popoli et al. 2011; Sanacora et al. 2013).

Previously, we reported that fluoxetine, a selective serotonin reuptake inhibitor (SSRI), acts as an agonist on astroglial 5- $\mathrm{HT}_{2 \mathrm{~B}}$ receptors (Kong et al. 2002). Acute treatment with fluoxetine activates $5-\mathrm{HT}_{2 \mathrm{~B}}$ receptors in astroglia, which results in transactivation of epidermal growth factor receptor (EGFR) with subsequent recruitment of its intracellular signal pathways, MAPK/ERK and PI3K/AKT (Li et al. 2008; Ren et al. 2015). The glycogen synthase kinase 3 (GSK-3), the downstream substrate of AKT, is an enzyme, whcih has been initially discovered as a deactivator of glycogen synthase (GS) that converts glucose to glycogen. In the brain in vivo, glycogen is mainly (if not exclusively) localised in astroglia (Ibrahim 1975; Hertz et 
al. 2015). The roles of glycogen are not limited to an emergency energy substrate. Glycogen turnover, i.e., interspersed glycogen synthesis and glycogenolysis, is indispensable for learning (Gibbs and Hutchinson 2012; Hertz et al. 2013). The acute memory-enhancing, as well as glycogenolysis-dependent effect of both fluoxetine and paroxetine has been also described (Gibbs and Hertz 2014). Knock-out of brain glycogen synthase abolishes learning of new motor and cognitive skills (Duran et al. 2013). In our laboratory, experiments with primary cultures of astroglial cells have shown that glycogenolysis is essential for many signalling processes, including those enabling $\mathrm{K}^{+}$buffering (Xu et al. 2013).

GSK-3 exists in two isoforms, GSK-3 $\alpha$ and GSK-3 $\beta$ with molecular weight of 51 and $47 \mathrm{kDa}$ respectively (Gould TD et al. 2005). High levels of GSK-3 $\beta$ are detected in the central nervous system (CNS) (Perez-Costas et al. 2010). AKT phosphorylates GSK-3 $\beta$ at serine-9 and serine-21, and down-regulates its activity (Fang et al. 2000). The GSK-3 $\beta$ is an important component of several signalling pathways, such as insulin/insulin-like growth factor (IGF-1) signalling, neurotrophic factor signalling, and the Wnt signalling pathway (Gould and Manji 2005). Alterations in GSK-3 $\beta$ activity were found in mood disorders, in Alzheimer's disease and in diabetes (Gould and Manji 2005).

Phosphatase and tensin homologue (PTEN) inhibits PI3K/AKT pathway by dephosphorylation of PI3K (Robbins and Hague 2016); whereas caveolae protein, caveolin 1 (Cav-1) that binds directly to PTEN, regulates membrane content and function of the latter (Xia et al. 2010). Caveolae are small lipid rafts of the plasma membrane which contribute to cell signalling (Sowa 2011). Caveolae formation and stabilisation depends on the key structural protein, caveolin (Smart et al. 1999), which occurs in three isoforms of caveolin 1 to 3 (Cav-1, -2, and -3) (Stary et al. 2012). Cav-1 is essential for formation of caveolae in endothelial cells, fibroblasts, and pneumocytes (Razani et al. 2001), whereas the role of Cav-2 remains undefined. Cav-3 is highly expressed as a homodimer in muscle (Chidlow and Sessa 2010). All 
three caveolin isoforms have been detected in CNS (Zschocke et al. 2002; Shin et al. 2005).

Previously, we have demonstrated that in astrocytes ammonium decreases GSK-3 $\beta$ phosphorylation and increases its activity via Cav-1/PTEN/PI3K/AKT signalling pathway. We hypothesised that chronic treatment with fluoxetine may affect glycogen content in astroglial cells via regulation of Cav-1 gene expression. In the present study, we have investigated (i) expression of Cav-1 mRNA and protein in primary astroglial cultures chronically treated with fluoxetine; (ii) effects of chronic treatment of primary astroglial cultures with fluoxetine on membrane content of PTEN and phosphorylation of AKT, and GSK-3 $\beta$; (iii) effects of chronic treatment with fluoxetine on glycogen content in astrocytes in vitro.

\section{Materials and methods}

\section{Cell cultures}

Primary cultures of mouse astrocytes were prepared from the neopallia of the cerebral hemispheres of newborn CD-1 mice as previously described (Hertz et al. 1998; Hertz et al. 1978); cells were sparsely seeded, and grown in Dulbecco's Minimum Essential Medium (DMEM) with $7.5 \mathrm{mM}$ glucose. After 2 weeks in vitro, $0.25 \mathrm{mM}$ dibutyryl cyclic AMP (dBcAMP) was included in the medium. These cultures are highly enriched in astrocytes ( $>95 \%$ purity of glial fibrillary acidic protein- (GFAP-) and glutamine synthetase-expressing astrocytes) (Hertz et al. 1985). Addition of dBcAMP leads to a morphological and functional differentiation as evidenced by the extension of cell processes and increases in several metabolic and functional activities characteristic of astrocytes in situ (Meier et al. 1991); in addition this treatment promotes $\mathrm{Ca}^{2+}$ flux through voltage-dependent channels (Hertz et al. 1989).

\section{Knock-down of Cav-1}

Transfection was performed as previously described (Li et al. 2008). To allow incorporation of siRNAs into astrocytes, 3-week-old astrocytes cultured in Primaria 
24-well culture plates were incubated in Dulbecco's medium without serum for $24 \mathrm{~h}$ on the day before transfection. Transfection solution containing $2 \mu$ l Oligofectamine, $40 \mu \mathrm{l}$ Opti-MEMI, and $2.5 \mu \mathrm{l}$ siRNA (666 ng) was added to the culture for $8 \mathrm{~h}$. In siRNA (-) control cultures, transfection solution without siRNA was added. Thereafter, 87.5 $\mu \mathrm{l}$ DMEM with $37.5 \mu \mathrm{l}$ serum was added to the cultures. Effective knockdown of Cav-1 was confirmed by Western blot three days after transfection.

\section{Membrane preparation}

A crude membrane preparation from astrocytes or brain tissue was made as previously described by Peng et al (1997). Cells from five 60-mm dishes were collected as one sample, homogenised in SET (0.315 M sucrose, $20 \mathrm{mM}$ TrisCl, and $1 \mathrm{mM}$ EDTA, $\mathrm{pH}$ 7.4), and centrifuged for $1 \mathrm{~h}$ at 140,000 g. The pellets were collected and resuspended in SET.

\section{Western blotting}

Protein content was determined by the Lowry method (Lowry et al. 1951), using bovine serum albumin as the standard. Samples containing $60 \mu \mathrm{g}$ protein were applied on slab gels of $10 \%$ polyacrylamide and electrophoresed. After transfer to polyvinylidene fluoride (PVDF) membranes, the samples were blocked by 5\% skim milk powder in TBS-T (30 mM Tris-HCl, $125 \mathrm{mM} \mathrm{NaCl}, 0.1 \%$ Tween 20) for $1 \mathrm{~h}$. The PVDF membranes were incubated with the first antibody, specific to Cav-1, p-AKT/AKT, p-GSK/GSK overnight at $4^{\circ} \mathrm{C}$, or PTEN and $\beta$-actin for $2 \mathrm{~h}$ at room temperature. After washing, the blots were incubated with peroxidase-conjugated affinity-purified goat-anti-mouse or goat-anti-rabbit horseradish antibody for $2 \mathrm{~h}$. Staining was visualised by ECL detection reagents. Digital images obtained using Gel-Imaging System (Tanon 4200, Shanghai, China). Optical density for each band was assessed using the Window Alpha-Ease TM FC 32-bit software.

\section{Determination of glycogen}


For determination of glycogen in cultured cells, a TECAN infinite M200 MicroplateAnalyzer (Lausanne, Switzerland) was used to record fluorescence intensity of NADPH, generated from $\mathrm{NADP}^{+}$by the action of glucose-6-phosphate dehydrogenase. This was done in untreated control cultures and in cultures treated with fluoxetine $(1 \mu \mathrm{M}, 10 \mu \mathrm{M})$ for 2 weeks. After 2 weeks treatment, the astrocytes were washed three times with ice-cold phosphate-buffered saline (PBS) and sonicated in $30 \mathrm{mM} \mathrm{HCl}$ (similar solution as the homogenised slices). The suspension was used to measure non-hydrolyzed glycosyl units of glycogen. Briefly, three $50 \mu \mathrm{l}$ aliquots were sampled. In the first aliquot, $150 \mu \mathrm{l}$ of acetate buffer $(0.1 \mathrm{M}, \mathrm{pH} 4.65)$ was added. In the second, $150 \mu \mathrm{l}$ of a solution containing $1 \%$ amyloglucosidase $(10 \mathrm{mg} / \mathrm{ml})$ in the acetate buffer was added in order to degrade remaining glycogen to glucose, and the mixture was incubated at room temperature for $30 \mathrm{~min}$. Subsequently the two aliquots were treated identically. Two $\mathrm{ml}$ of Tris- $\mathrm{HCl}$ buffer $(0.1 \mathrm{M}, \mathrm{pH} 8.1)$ containing 3.3 $\mathrm{mM} \mathrm{MgCl} 2,0.2 \mathrm{mM}$ ATP, $25 \mathrm{ug} / \mathrm{ml}$ NADP, $4 \mu \mathrm{g} / \mathrm{ml}$ hexokinase, and $2 \mu \mathrm{g} / \mathrm{ml}$ glucose-6-phosphate dehydrogenase was added to each, and the mixture was incubated at room temperature for $30 \mathrm{~min}$. The fluorescence of the NADPH formed in amounts equivalent to glucose metabolised by hexokinase was then read (excitation $340 \mathrm{~nm}$; emission $450 \mathrm{~nm}$ ). The first aliquot measures the sum of glucose and glucose-6-phosphate in the tissue, whereas the second aliquot in addition to those also measures the glycosyl units from glycogen remaining in the tissue. Determination of the difference between these two aliquots provides a measurement of the amount of the latter. The third aliquot was used to measure the protein content by the Lowry method to normalise the glycogen contents (nmol) per mg protein. A standard curve was made to show fluorescence intensity at different glucose concentrations and glycogen content was calculated, using a conversion factor based on a molecular weight of $180 \mathrm{~g} / \mathrm{mol}$ for free glucose, but $162 \mathrm{~g} / \mathrm{mol}$ per glycosyl unit of glycogen.

\section{Materials}

Chemicals for preparation of culturing medium were purchased from Sigma (St. Louis, MO, USA) and horse serum from Invitrogen (Carlsbad, CA, USA). Most chemicals, 
including dBcAMP and fluoxetine were purchased from Sigma (St. Louis, MO, USA). Antibodies specific to Cav-1 antibody and PTEN were obtained from Santa Cruz Biotechnology (Santa Cruz, CA, USA). Antibodies specific to p-AKT, AKT, p-GSK-3 $\beta$ or GSK-3 $\beta$ were obtained from Cell Signaling Technology (Cell Signaling, USA). Antibody specific to $\beta$-actin was obtained from Sigma-Aldrich (Sigma, USA). The second antibody goat anti-mouse IgG-HRP was purchased from Promega (Madison, USA). The second antibody goat anti-rabbit IgG-HRP and Cav-1 siRNA (catalog no. sc-29942) were purchased from Santa Cruz Biotechnology (Santa Cruz, CA, USA). Scramble siRNA (5'-ACGACTAGCCTGAACTCAA-3') was synthesised by Sigma (St. Louis, MO, USA). Opti-MEMI and Oligofectamine were purchased from Invitrogen (Carlsbad, CA, USA). Adenosine triphosphate (ATP), nicotinamide adenine dinucleotide phosphate (NADP), hexokinase, glucose-6-phosphate dehydrogenase, and amyloglucosidase were purchased from Sigma (St. Louis, MO, USA).

\section{Statistics}

The differences between individual groups were analysed by one-way ANOVA followed by Fisher's LSD test. The level of significance was set at $p<0.05$.

\section{Results}

Acute treatment

In order to differentiate acute and chronic effects of the drug, we obtained the concentration-dependence and monitored the time course of AKT phosphorylation in the context of acute treatment. Acute treatment with fluoxetine for $10 \mathrm{~min}$ increased AKT phosphorylation only at $5 \mu \mathrm{M}(18.9 \pm 3.4 \%)$ and at $10 \mu \mathrm{M}(21.1 \pm 4.5 \%)$. Twenty min treatment increased AKT phosphorylation in a concentration-dependent manner with $0.1 \mu \mathrm{M}$ to $10 \mu \mathrm{M}$ fluoxetine causing $20.9 \pm 6.3 \%$ to $62.3 \pm 3.0 \%$ increase (Fig. 1). The highest level of phosphorylation was observed at $10 \mu \mathrm{M}$ being $162.3 \pm 3.0 \%$, of control group. The increase in AKT phosphorylation declined after 
40 min with only a small increase at $10 \mu \mathrm{M}(17.8 \pm 3.7 \%)$ and disappeared after $2 \mathrm{hr}$ of treatment (Fig. 1).

\section{Chronic treatment}

Treatment of cultured astrocytes with fluoxetine for 2 weeks regulated expression of Cav-1 protein in a concentration-dependent manner with $0.1,0.5$ and $1 \mu \mathrm{M}$ fluoxetine causing a significant down-regulation but 5 and $10 \mu \mathrm{M}$ a significant up-regulation (Fig. 2A). The lowest level was observed at $1 \mu \mathrm{M}$ being $52.6 \pm 1.9 \%$ of control, whereas the highest level of expression was determined at $10 \mu \mathrm{M}$ being $147.8 \pm 3.1 \%$ of control group.

Similar bi-phasic concentration-dependence was also observed in membrane PTEN content with $0.1,0.5$ and $1 \mu \mathrm{M}$ fluoxetine causing a significant down-regulation but 5 and $10 \mu \mathrm{M}$ a significant up-regulation (Fig. 2B). The lowest level was observed at 1 $\mu \mathrm{M}$ being $59.7 \pm 7.8 \%$ of control, whereas the highest level of expression at $10 \mu \mathrm{M}$ being $139.7 \pm 3.9 \%$ of control group.

Treatment of cultured astrocytes with fluoxetine for 2 weeks regulated AKT phosphorylation in a concentration-dependent manner with $0.1,0.5$ and $1 \mu \mathrm{M}$ fluoxetine causing a significant up-regulation (from $19.2 \pm 0.6 \%$ to $33.3 \pm 8.5 \%$ ), whereas 5 and $10 \mu \mathrm{M}$ a significant down-regulation (from $26.1 \pm 4.6 \%$ to $29.6 \pm 4.2 \%$ ) (Fig. 3A). There is no significant difference between $0.1,0.5$ and $1 \mu \mathrm{M}$ and between 5 and $10 \mu \mathrm{M}$.

Similar effect was also observed in GSK-3 $\beta$ phosphorylation. Treatment of cultured astrocytes with fluoxetine for 2 weeks affected GSK-3 $\beta$ phosphorylation in a concentration-dependent manner with $0.1,0.5$ and $1 \mu \mathrm{M}$ fluoxetine causing a significant up-regulation (from $44.2 \pm 16.3 \%$ to $58.2 \pm 10.5 \%$ ) but significant down-regulation (from $39.3 \pm 4.6 \%$ to $40.5 \pm 14.2 \%$ ) was observed at 5 and $10 \mu \mathrm{M}$ 
(Fig. 3B). There is no significant difference between $0.1,0.5$ and $1 \mu \mathrm{M}$ and between 5 and $10 \mu \mathrm{M}$.

\section{Effects of Cav-1 siRNA}

Cav-1 siRNA reduced protein expression of Cav-1 to $33.9 \pm 6.8 \%$ of the control group after 3 days of transfection (Fig. 4A). Cav-1 siRNA had no effect on $0.1,0.5$ and 1 $\mu \mathrm{M}$ fluoxetine-induced increase of AKT phosphorylation (increased by $23.8 \pm 4.9 \%$, $41.3 \pm 6.6 \%$ and $36.5 \pm 3.5 \%$, respectively), but abolished the decrease of AKT phosphorylation by 5 and $10 \mu \mathrm{M}$ fluoxetine $(102.5 \pm 4.8 \%$ and $104.1 \pm 2.3 \%$ of control group, respectively) (Fig. 4B). Similar results was also obtained in GSK-3 $\beta$ phosphorylation (respectively increased by $20.2 \pm 6.0 \%, 33.2 \pm 7.5 \%$ and $22.3 \pm 1.3 \%$ at $0.1,0.5$ and $1 \mu \mathrm{M} ; 102.2 \pm 3.7 \%$ and $103.9 \pm 5.5 \%$ of control group at 5 and $10 \mu \mathrm{M}$ ) (Fig. 4C).

\section{Effect of fluoxetine on glycogen content}

Treatment with $1 \mu \mathrm{M}$ fluoxetine for 2 weeks increased glycogen content to $150.7 \pm$ $13.6 \%$ of the control group. In contrast, treatment with $10 \mu \mathrm{M}$ fluoxetine decreased glycogen content to $54.0 \pm 10.2 \%$ of the control (Fig. 5).

\section{Discussion}

In addition to regulation of glycogen synthesis, GSK-3 $\beta$ is involved in diverse signalling pathways, such as insulin/insulin-like growth factor (IGF-1) signalling, neurotrophic factor signalling, and the Wnt signalling (Gould and Manji 2005). The signalling roles of GSK-3 $\beta$ are implicated in several human diseases, such as type 2 diabetes, Alzheimer's disease, cancer, cardiac hypertrophy and hypertension (Phukan et al. 2010). Some biological functions of GSK-3 $\beta$ may be relevant to mood disorders. It includes neuroprotection, regulation of monaminergic signalling, brain metabolism and circadian rhythms, and modulating estrogen and glucocorticoid activity (Gould and Manji 2005). 
Increased GSK-3 $\beta$ activity is generally accepted to be one of mechanisms underlying major depression and bipolar disorder. Increase in GSK-3 $\beta$ activity results from up-regulation of GSK-3 $\beta$ gene expression or down-regulation of GSK-3 $\beta$ phosphorylation and hence decrease in the ratio between phosphorylated GSK-3 $\beta$ and total GSK-3 $\beta$. Evidence for the involvement of GSK-3 $\beta$ in major depression is obtained from both animal models (Szymańska et al. 2009) and depressed patients (Pláteník et al. 2014). Increase in GSK-3 $\beta$ activity in depressed animals can be reversed by treatment with SSRIs. Mice overexpressing GSK-3 $\beta$ shows prodepressant-like phenotype and increased sensitivity to chronic mild stress; these behaviour changes can be prevented by chronic, but not by acute treatment with fluoxetine (Zhang et al. 2013). In prenatally stressed rats GSK-3 $\beta$ levels were significantly elevated in the frontal cortex, but not in the hippocampus (Szymańska et al. 2009), while concentration of phosphorylated GSK-3 $\beta$ was decreased only in the former structure. Chronic treatment with antidepressant drugs diminished stress-induced alterations in GSK-3 $\beta$ and phospho-GSK-3 $\beta$ only in the frontal cortex (Szymańska et al. 2009). In addition, chronic treatment with citalopram alleviated the depression-like behaviors and reversed the decrease of the phosphorylated GSK-3 $\beta$ in stressed rats (Liu et al. 2012). In postmortem prefrontal cortex of patients with MDD and MDD with suicide, the level of phosphorylated GSK-3 $\beta$ was decreased (Karege et al. 2012). In elderly depressed patients and Alzheimer's disease patients with depression, a lower level of phosphorylated GSK-3 $\beta$ in platelets correlated with severity of depression (Diniz et al. 2011; Pláteník et al. 2014).

However, there are data demonstrating increased activity of GSK-3 $\beta$ following antidepressant treatment. For example, long-term treatment with sertraline increased GSK-3 $\beta$ activity in platelets of patients with late-life depression (Joaquim et al. 2012). Our present findings suggest that this controversy may result from none-linear effects of SSRIs on regulation of Cav-1 gene expression in astrocytes. Astrocytes express all three isoforms of caveolins (Virgintino et al. 2002), which play complex rolea that are not completely understood. Recently, we have reported that treatment of cultured 
astrocytes with ammonium as well as treatment of animals with urease up-regulates astroglial Cav-1 gene expression, which, in turn, increases membrane content of PTEN, inhibits PI3K/AKT signalling, and enhances GSK-3 $\beta$ activity (Wang et al. 2016).

In the present study, we found that acute treatment with fluoxetine at concentrations of 0.5 to $10 \mu \mathrm{M}$ increased AKT phoaphorylation in a concentration-dependent manner. This is in agreement with our previously report (Ren et al. 2015) although it contrasts the bi-phasic effect by chronic drug treatment. In addition, this stimulation lasted only for $40 \mathrm{~min}$, and thereafter $\mathrm{p}$-AKT level showed no significant difference from control group from 2 hours to 3 days (data not shown) after drug treatment.

Second, we found that chronic treatment with fluoxetine decreased Cav-1 mRNA and protein expression in cultured astrocytes at lower concentrations, but increased it at higher concentrations. Since Cav-1 contains sequences for PTEN binding (Xia et al. 2010), the up- or down-regulation of Cav-1 expression, in turn, increases or decreased membrane content of PTEN. PTEN is a lipid/protein phosphatase, which induces dephosphorylation and inhibition of PI3K (Robbins and Hague 2016). We also observed that AKT phosphorylation was increased at lower concentrations, but decreased at higher concentrations. The involvement of Cav-1 was further confirmed by the abolishment of fluoxetine-induced inhibition of AKT phosphorylation at higher concentrations by Cav-1 siRNA.

Third, we found that chronic treatment with fluoxetine decreased GSK-3 $\beta$ phosphorylation in cultured astrocytes at lower concentrations, but increased it at higher concentrations. Down-regulation of GSK-3 $\beta$ phosphorylation is also related to Cav-1 since Cav-1 siRNA abolished fluoxetine-induced inhibition of AKT phosphorylation at higher concentrations. The regulation of GSK-3 $\beta$ phosphorylation and activity will change the activity of glycogen synthetase, which, in turn, affects glycogen content in astrocytes. Here, we found that fluoxetine increased glycogen 
content in cultured astrocytes at lower concentrations, but decreased it at higher concentrations. This may be important for behavioural effects of SSRIs. Glycogen turnover, i.e., interspersed glycogen synthesis and glycogenolysis, is indispensable during learning (Gibbs and Hutchinson 2012; Hertz et al. 2013). The acute memory-enhancing, glycogenolysis-dependent effect of both fluoxetine and paroxetine has been mentioned (O'Dowd et al. 1994; 1995; Gibbs and Hertz 2014; Suzuki et al. 2011; Gibbs and Hertz 2014; Gao et al. 2016). Knock-out of brain glycogen synthase abolishes learning of new motor and cognitive skills (Duran et al. 2013).

In conclusion, we demonstrated, for the first time, that chronic treatment with fluoxetine decreases GSK-3 $\beta$ activity via stimulation of PI3K/AKT pathway by decreasing Cav-1 gene expression and membrane content of PTEN at lower concentrations, but increases GSK-3 $\beta$ activity via inhibition of PI3K/AKT pathway by increasing Cav-1 gene expression and membrane content of PTEN at higher concentrations. The combined concentration of fluoxetine and its primary metabolite norfluoxetine in plasma of fluoxetine-treated patients is around 1-2 $\mu \mathrm{M}$ (Bolo et al. 2000; Henry et al. 2005). However, brain concentration of the drug reaches 15-25 $\mu \mathrm{M}$ (Bolo et al. 2000; Henry et al. 2005). Thus bi-phasic regulation of GSK-3 $\beta$ activity and glycogen content in astrocytes, as well as in other types of cells in peripheral tissues may contribute to both therapeutic and side effects of the drug. 


\section{References}

Barley K, Dracheva S, Byne W (2009) Subcortical oligodendrocyte- and astrocyte-associated gene expression in subjects with schizophrenia, major depression and bipolar disorder. Schizophr Res 112:54-64

Bernard R, Kerman IA, Thompson RC, Jones EG, Bunney WE, Barchas JD, Schatzberg AF, Myers RM, Akil H, Watson SJ (2011) Altered expression of glutamate signaling, growth factor, and glia genes in the locus coeruleus of patients with major depression. Mol Psychiatry 16:634-646

Bolo NR, Hodé Y, Nédélec JF, Lainé E, Wagner G, Macher JP (2000) Brain pharmacokinetics and tissue distribution in vivo of fluvoxamine and fluoxetine by fluorine magnetic resonance spectroscopy. Neuropsychopharmacology 23:428-438

Chidlow JH Jr, Sessa WC (2010) Caveolae, caveolins, and cavins: complex control of cellular signalling and inflammation. Cardiovasc Res 86:219-225

Diniz BS, Talib LL, Joaquim HP, de Paula VR, Gattaz WF, Forlenza OV (2011) Platelet GSK3B activity in patients with late-life depression: marker of depressive episode severity and cognitive impairment? World J Biol Psychiatry 12:216-222

Duran J, Saez I, Gruart A, Guinovart JJ, Delgado-García JM (2013) Impairment in long-term memory formation and learning-dependent synaptic plasticity in mice lacking glycogen synthase in the brain. J Cereb Blood Flow Metab 33:550-556

Fang X, Yu SX, Lu Y, Bast RC Jr, Woodgett JR, Mills GB (2000) Phosphorylation and inactivation of glycogen synthase kinase 3 by protein kinase A. Proc Natl Acad Sci U S A 97:11960-11965

Gao V, Suzuki A, Magistretti PJ, Lengacher S, Pollonini G, Steinman MQ, Alberini CM (2016) Astrocytic $\beta 2$-adrenergic receptors mediate hippocampal long-term memory consolidation. Proc Natl Acad Sci U S A 113:8526-8531

Gibbs ME, Hertz L (2014) Serotonin mediation of early memory formation via $5-\mathrm{HT}_{2 \mathrm{~B}}$ receptor-induced glycogenolysis in the day-old chick. Front Pharmacol 5:54

Gibbs ME, Hutchinson DS (2012) Rapid turnover of glycogen in memory formation. Neurochem Res 37:2456-2463

Gibbs ME, Hutchinson DS (2012) Rapid turnover of glycogen in memory formation. Neurochem Res 37:2456-2463

Gould TD, Manji HK (2005) Glycogen synthase kinase-3: a putative molecular target for lithium mimetic drugs. Neuropsychopharmacology 30:1223-1237 
Henry ME, Schmidt ME, Hennen J, Villafuerte RA, Butman ML, Tran P, Kerner LT, Cohen B, Renshaw PF (2005) A comparison of brain and serum pharmacokinetics of R-fluoxetine and racemic fluoxetine: A 19-F MRS study. Neuropsychopharmacology 30:1576-1583

Hertz L, Bender AS, Woodbury DM, White HS (1989) Potassium-stimulated calcium uptake in astrocytes and its potent inhibition by nimodipine. J Neurosci Res 22:209-215

Hertz L, Juurlink BHJ, Szuchet S (1985) Cell cultures. In: Lajtha A (ed) Handbook of Neurochemistry. Plenum Press, New York, pp 603-661

Hertz L, Peng L, Lai JC (1998) Functional studies in cultured astrocytes. Methods 16:293-310

Hertz L, Schousboe A, Boechler N, Mukerji S, Fedoroff S (1978) Kinetic characteristics of the glutamate uptake into normal astrocytes in cultures. Neurochem Res 3:1-14

Hertz L, Xu J, Song D, Du T, Li B, Yan E, Peng L (2015) Astrocytic glycogenolysis: mechanisms and functions. Metab Brain Dis 30:317-333

Hertz L, Xu J, Song D, Du T, Yan E, Peng L (2013) Brain glycogenolysis, adrenoceptors, pyruvate carboxylase, $\mathrm{Na}^{+}{ }^{+} \mathrm{K}^{+}$-ATPase and Marie E. Gibbs' pioneering learning studies. Front Integr Neurosci 7:20

Ibrahim MZ (1975) Glycogen and its related enzymes of metabolism in the central nervous system. Adv Anat Embryol Cell Biol 52:3-89

Joaquim HP, Talib LL, Forlenza OV, Diniz BS, Gattaz WF (2012) Long-term sertraline treatment increases expression and decreases phosphorylation of glycogen synthase kinase-3B in platelets of patients with late-life major depression. J Psychiatr Res 46:1053-1058

Karege F, Perroud N, Burkhardt S, Fernandez R, Ballmann E, La Harpe R, Malafosse A (2012) Protein levels of $\beta$-catenin and activation state of glycogen synthase kinase-3 $\beta$ in major depression. A study with postmortem prefrontal cortex. J Affect Disord 136:185-188

Klempan TA, Sequeira A, Canetti L, Lalovic A, Ernst C, ffrench-Mullen J, Turecki G (2009) Altered expression of genes involved in ATP biosynthesis and GABAergic neurotransmission in the ventral prefrontal cortex of suicides with and without major depression. Mol Psychiatry 14:175-189

Kong EK, Peng L, Chen Y, Yu AC, Hertz L (2002) Up-regulation of 5-HT $2 \mathrm{~B}$ receptor density and receptor-mediated glycogenolysis in mouse astrocytes by long-term fluoxetine administration. Neurochem Res 27:113-120 
Li B, Zhang S, Zhang H, Nu W, Cai L, Hertz L, Peng L (2008) Fluoxetine-mediated 5- $\mathrm{HT}_{2 \mathrm{~B}}$ receptor stimulation in astrocytes causes EGF receptor transactivation and ERK phosphorylation. Psychopharmacology 201:443-458.

Liu S, Sun N, Xu Y, Yang C, Ren Y, Liu Z, Cao X, Sun Y, Xu Q, Zhang K, Shen Y (2012) Possible association of the GSK3 $\beta$ gene with the anxiety symptoms of major depressive disorder and P300 waveform. Genet Test Mol Biomarkers 16:1382-1389

Lowry OH, Rosebrough NJ, Farr AL, Randall RJ (1951) Protein measurement with the Folin phenol reagent. J Biol Chem 193:265-275

McNally L, Bhagwagar Z, Hannestad J (2008) Inflammation, glutamate, and glia in depression: a literature review. CNS Spectr 13:501-510

Meier E, Hertz L, Schousboe A (1991) Neurotransmitters as developmental signals. Neurochem Int 19:1-15

O'Dowd BS, Barrington J, Ng KT, Hertz E, Hertz L (1995) Glycogenolytic response of primary chick and mouse cultures of astrocytes to noradrenaline across development. Brain Res Dev Brain Res 88:220-223

O'Dowd BS, Gibbs ME, Ng KT, Hertz E, Hertz L (1994) Astrocytic glycogenolysis energizes memory processes in neonate chicks. Brain Res Dev Brain Res 78:137-141

Peng L, Martin-vasallo P, Sweadner KJ (1997) Isoforms of Na, K-ATPase alpha and beta subunits in the rat cerebellum and in granule cell cultures. J Neurosci 17:3488-3502

Perez-Costas E, Gandy JC, Melendez-Ferro M, Roberts RC, Bijur GN (2010) Light and electron microscopy study of glycogen synthase kinase-3beta in the mouse brain. PLoS One 5:e8911

Phukan S, Babu VS, Kannoji A, Hariharan R, Balaji VN (2010) GSK3beta: role in therapeutic landscape and development of modulators. Br J Pharmacol 160:1-19

Pláteník J, Fišar Z, Buchal R, Jirák R, Kitzlerová E, Zvěřová M, Raboch J (2014) GSK3ß, CREB, and BDNF in peripheral blood of patients with Alzheimer's disease and depression. Prog Neuropsychopharmacol Biol Psychiatry 50:83-93

Popoli M, Yan Z, McEwen BS, Sanacora G (2011) The stressed synapse: the impact ofstress and glucocorticoids on glutamate transmission. Nat Rev Neurosci 13:22-37

Rajkowska G, Stockmeier CA (2013) Astrocyte pathology in major depressive disorder: insights from human postmortem brain tissue. Curr Drug Targets 14:1225-1236 
Razani B, Engelman JA, Wang XB, Schubert W, Zhang XL, Marks CB, Macaluso F, Russell RG, Li M, Pestell RG, Di Vizio D, Hou H Jr, Kneitz B, Lagaud G, Christ GJ, Edelmann W, Lisanti MP (2001) Caveolin-1 null mice are viable but show evidence of hyperproliferative and vascular abnormalities. J Biol Chem 276:38121-38138

Ren J, Song D, Bai Q, Verkhratsky A, Peng L (2015) Fluoxetine induces alkalinization of astroglial cytosol through stimulation of sodium-hydrogen exchanger 1: dissection of intracellular signaling pathways. Front Cell Neurosci 9:61

Robbins HL, Hague A (2016) The PI3K/Akt Pathway in Tumors of Endocrine Tissues. Front Endocrinol (Lausanne) 6:188

Sanacora G, Banasr M (2013) From pathophysiology to novel antidepressant drugs: glial contributions to the pathology and treatment of mood disorders. Biol Psychiatry 73:1172-1179

Sequeira A, Mamdani F, Ernst C, Vawter MP, Bunney WE, Lebel V, Rehal S, Klempan T, Gratton A, Benkelfat C, Rouleau GA, Mechawar N, Turecki G (2009) Global brain gene expression analysis links glutamatergic and GABAergic alterations to suicide and major depression. PLoS One 4:e6585

Shin T, Kim H, Jin JK, Moon C, Ahn M, Tanuma N, Matsumoto Y (2005) Expression of caveolin-1, -2 , and -3 in the spinal cords of Lewis rats with experimental autoimmune encephalomyelitis. J Neuroimmunol 165:11-20

Smart EJ, Graf GA, McNiven MA, Sessa WC, Engelman JA, Scherer PE, Okamoto T, Lisanti MP (1999) Caveolins, liquid-ordered domains, and signal transduction. Mol Cell Biol 19:7289-7304

Sowa G (2011) Novel insights into the role of caveolin-2 in cell- and tissue-specific signaling and function. Biochem Res Int 2011:809259

Stary CM, Tsutsumi YM, Patel PM, Head BP, Patel HH, Roth DM (2012) Caveolins: targeting pro-survival signaling in the heart and brain. Front Physiol 3:393

Suzuki A, Stern SA, Bozdagi O, Huntley GW, Walker RH, Magistretti PJ, Alberini CM (2011) Astrocyte-neuron lactate transport is required for long-term memory formation. Cell 144:810-823

Szymańska M, Suska A, Budziszewska B, Jaworska-Feil L, Basta-Kaim A, Leśkiewicz M, Kubera M, Gergont A, Kroczka S, Kaciński M, Lasoń W (2009) Prenatal stress decreases glycogen synthase kinase-3 phosphorylation in the rat frontal cortex. Pharmacol Rep 61:612-620

Verkhratsky A, Butt AM (2013) Glial Physiology and Pathophysiology. Wiley-Blackwell, Chichester 
Verkhratsky A, Rodríguez JJ, Steardo L (2014) Astrogliopathology: a central element of neuropsychiatric diseases? Neuroscientist 20:576-588

Virgintino D, Robertson D, Errede M, Benagiano V, Tauer U, Roncali L, Bertossi M (2002) Expression of caveolin-1 in human brain microvessels. Neuroscience 115:145-152

Wang W, Gu L, Verkhratsky A, Peng L (2016) Ammonium Increases TRPC1 Expression Via Cav-1/PTEN/AKT/GSK3 $\beta$ Pathway. Neurochem Res. doi: 10.1007/s11064-016-2004-z

Xia H, Khalil W, Kahm J, Jessurun J, Kleidon J, Henke CA (2010) Pathologic caveolin-1 regulation of PTEN in idiopathic pulmonary fibrosis. Am J Pathol 176:2626-2637

Xu J, Song D, Xue Z, Gu L, Hertz L, Peng L (2013) Requirement of glycogenolysis for uptake of increased extracellular $\mathrm{K}^{+}$in astrocytes: potential implications for $\mathrm{K}^{+}$homeostasis and glycogen usage in brain. Neurochem Res 38:472-485

Zhang K, Song X, Xu Y, Li X, Liu P, Sun N, Zhao X, Liu Z, Xie Z, Peng J (2013) Continuous GSK-3 $\beta$ overexpression in the hippocampal dentate gyrus induces prodepressant-like effects and increases sensitivity to chronic mild stress in mice. J Affect Disord 146:45-52

Zschocke J, Manthey D, Bayatti N, van der Burg B, Goodenough S, Behl C (2002) Estrogen receptor alpha-mediated silencing of caveolin gene expression in neuronal cells. J Biol Chem 277:38772-38780 


\section{Figure legends}

Figure 1. The level of AKT phosphorylation induced by acute treatment with fluoxetine.

Cells were incubated with 0 (Control), $0.1,0.5,1,5$ and $10 \mu \mathrm{M}$ fluoxetine for 10, 20, $40 \mathrm{~min}$ or 2 hrs. A: Immunoblots from representative experiments. Bands of $60 \mathrm{kDa}$ represent p-AKT (Ser473) and total AKT. Similar results were obtained from three independent experiments. B: Phosphorylated AKT and total AKT in drug-treated groups were normalised with control group respectively. Average AKT phosphorylation was quantified as ratio between normalised p-AKT and AKT. SEM values are indicated by vertical bars. *Indicates statistically significant $(\mathrm{P}<0.05)$ difference from control groups at the same time period.

Figure 2. Cav-1 protein expression and PTEN membrane content in primary cultures of mouse astrocytes treated with fluoxetine for 2 weeks.

A: Cells were incubated with 0 (Control), 0.1, 0.5, 1,5 and $10 \mu \mathrm{M}$ fluoxetine for 2 weeks. Immunoblots from representative experiments are shown on the top; bands of $23 \mathrm{kDa}$ and $42 \mathrm{kDa}$ represent $\mathrm{Cav}-1$ and $\beta$-actin. Similar results were obtained from three independent experiments. Graph at the bottom shows average Cav-1 protein expression quantified as ratio between Cav-1 and $\beta$-actin. Cav-1 to $\beta$-actin ratios were normalised to the control. SEM values are indicated by vertical bars. *Indicates statistically significant $(\mathrm{P}<0.05)$ difference from control, 5 and $10 \mu \mathrm{M}$ groups. \#Indicates statistically significant $(\mathrm{P}<0.05)$ difference from control, $0.1,0.5$ and $1 \mu \mathrm{M}$ groups.

B: Cells were incubated with 0 (Control), $0.1,0.5,1,5$ and $10 \mu \mathrm{M}$ fluoxetine for 2 weeks. Immunoblots from representative experiments are shown on the top; bands of $55 \mathrm{kDa}$ and $42 \mathrm{kDa}$ represent PTEN and $\beta$-actin. Similar results were obtained from three independent experiments. Graph at the bottom shows average PTEN membrane 
content was quantified as ratios between PTEN and $\beta$-actin. Ratios between PTEN and $\beta$-actin were normalised to the control. SEM values are indicated by vertical bars. *Indicates statistically significant $(\mathrm{P}<0.05)$ difference from control, 5 and $10 \mu \mathrm{M}$ groups. \#Indicates statistically significant $(\mathrm{P}<0.05)$ difference from control, $0.1,0.5$ and $1 \mu \mathrm{M}$ groups.

Figure 3. The level of phosphorylation of AKT and GSK-3 $\beta$ in primary cultures of mouse astrocytes treated with fluoxetine for 2 weeks.

A: Cells were incubated with 0 (Control), 0.1, 0.5, 1, 5 and $10 \mu \mathrm{M}$ fluoxetine for 2 weeks. Immunoblots from representative experiments are shown on the top; bands of $60 \mathrm{kDa}$ represent p-AKT (Ser473) and total AKT. Similar results were obtained from three independent experiments. Graph at the bottom shows changes in phosphorylated AKT and total AKT in drug-treated groups, which were normalised to the controls. Average AKT phosphorylation was quantified as ratios between normalised p-AKT and AKT. SEM values are indicated by vertical bars. *Indicates statistically significant $(\mathrm{P}<0.05)$ difference from control, 5 and $10 \mu \mathrm{M}$ groups. \#Indicates statistically significant $(\mathrm{P}<0.05)$ difference from control, $0.1,0.5$ and $1 \mu \mathrm{M}$ groups.

B: Cells were incubated with 0 (Control), 0.1, 0.5, 1, 5 and $10 \mu \mathrm{M}$ fluoxetine for 2 weeks. Immunoblots from representative experiments are shown on the top; bands of $43 \mathrm{kDa}$ represent $\mathrm{p}-\mathrm{GSK}-3 \beta$ and total GSK-3 $\beta$. Similar results were obtained from three independent experiments. Graph at the bottom shows changes in phosphorylated GSK-3 $\beta$ and total GSK-3 $\beta$ in drug-treated groups normalised to the controls. Average GSK-3 $\beta$ phosphorylation was quantified as ratios between normalised GSK-3 $\beta$ and GSK-3 $\beta$ Average. SEM values are indicated by vertical bars. *Indicates statistically significant $(\mathrm{P}<0.05)$ difference from control, 5 and $10 \mu \mathrm{M}$ groups. \#Indicates statistically significant $(\mathrm{P}<0.05)$ difference from control, $0.1,0.5$ and $1 \mu \mathrm{M}$ groups. 
Figure 4. The effects of Cav-1 siRNA on phosphorylation of AKT and GSK-3 $\beta$ in primary cultures of mouse astrocytes treated with fluoxetine for 2 weeks.

Cells were treated with either transfection solution without siRNA [siRNA (-)] (Control), with scrambled siRNA or siRNA specific to Cav-1 [siRNA $(+)$ ] for three days. Thereafter cells were incubated with 0 (Control), 0.1, 0.5, 1, 5 and $10 \mu \mathrm{M}$ fluoxetine for 2 weeks.

A: Left: Immunoblots from representative experiments; bands of $23 \mathrm{kDa}$ and $42 \mathrm{kDa}$ represent Cav-1 and $\beta$-actin. Similar results were obtained from three independent experiments. Right: average Cav-1 protein expression quantified as ratios between Cav-1 and $\beta$-actin. Ratios between Cav-1 and $\beta$-actin were normalised to the control. SEM values are indicated by vertical bars. *Indicates statistically significant $(\mathrm{P}<0.05)$ difference from control and scrambled siRNA (-) groups.

B: Left: Immunoblots from representative experiments; bands of $60 \mathrm{kDa}$ represent p-AKT (Ser473) and total AKT. Similar results were obtained from three independent experiments. Right: Phosphorylated AKT and total AKT in drug-treated groups were normalised with control group respectively. Average AKT phosphorylation was quantified as ratios between normalised p-AKT and AKT. SEM values are indicated by vertical bars. *Indicates statistically significant $(\mathrm{P}<0.05)$ difference from control, 5 and $10 \mu \mathrm{M}$ groups.

$\mathrm{C}$ : Left: Immunoblots from representative experiments; bands of $46 \mathrm{kDa}$ represent p-GSK-3 $\beta$ and total GSK-3 $\beta$. Similar results were obtained from three independent experiments. Right: Phosphorylated GSK-3 $\beta$ and total GSK-3 $\beta$ in drug-treated groups were normalised with control group respectively. Average GSK-3 $\beta$ phosphorylation was quantified as ratios between normalised GSK-3 $\beta$ and GSK-3 $\beta$ Average. SEM values are indicated by vertical bars. *Indicates statistically significant $(\mathrm{P}<0.05)$ difference from control, 5 and $10 \mu \mathrm{M}$ groups. 
Figure 5. Effect of fluoxetine on the glycogen content in cultured astrocytes.

Cultured astrocytes were incubated in untreated control cultures and in cultures treated with fluoxetine $(1 \mu \mathrm{M}$ or $10 \mu \mathrm{M})$ for 2 weeks. After the experiment glycogen was determined by measuring glucose content fluorometrically before and after breakdown of remaining glycogen in the cells. Average glycogen contents are indicated as percentages of those under control conditions. All values are expressed as mean \pm SEM, indicated by vertical bars and are from 8 to 10 individual cultures. *Statistically significant $(\mathrm{P}<0.05)$ difference from control. 
1

2

3

4

5

6

7

8

9

10

11

12

13

14

15

16

17

18

19

20

21

22

23

24

25

26

27

28

29

30

31

32

33

34

35

36

37

38

39

40

41

42

43

44

45

46

47

48

49

50

51

52

53

54

55

56

57

58

59

60

A
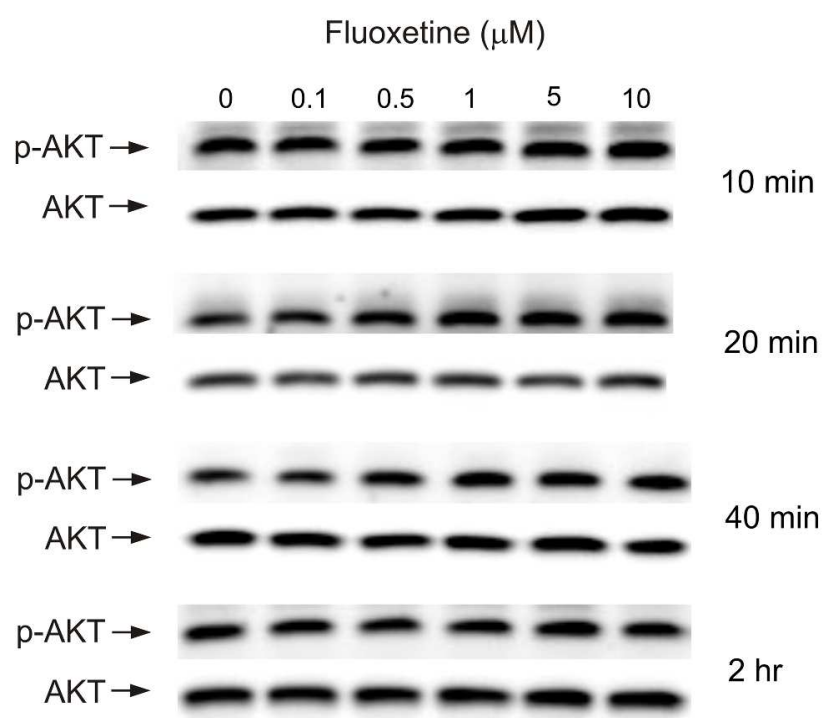

B

Fluoxetine $(\mu \mathrm{M})$

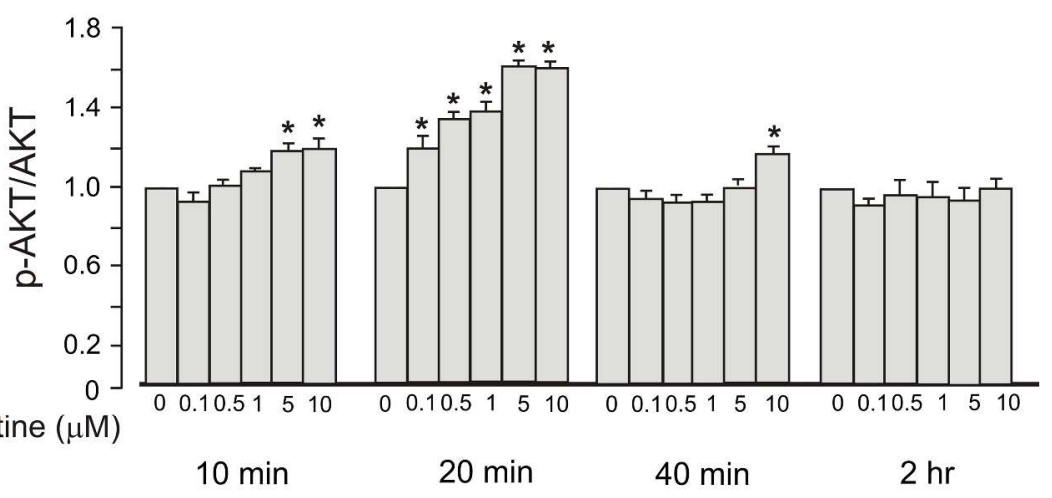

Fig. 1 
A
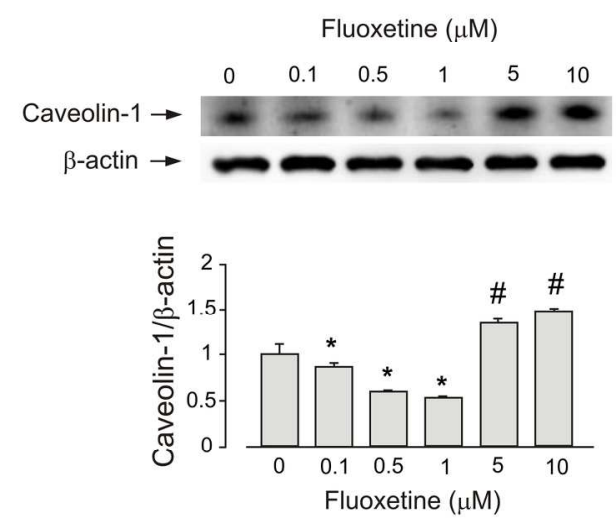

B
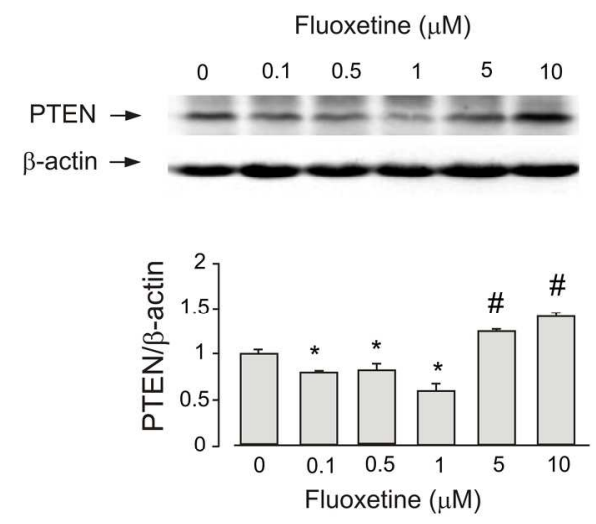

Fig. 2

$184 \times 134 \mathrm{~mm}(300 \times 300$ DPI $)$ 
A
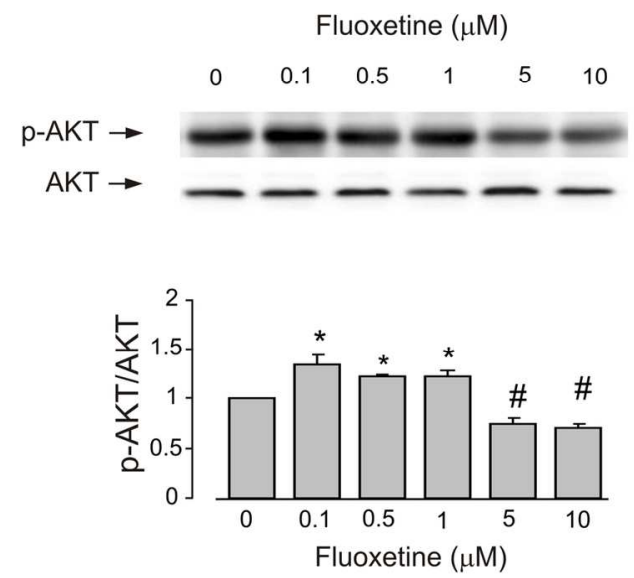

B
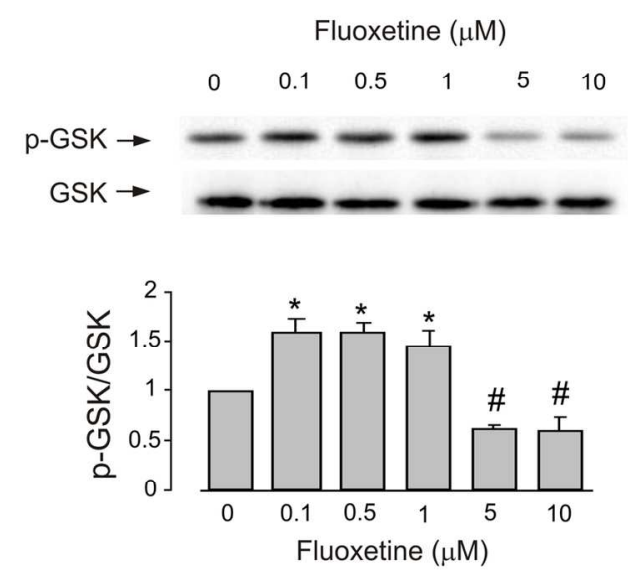

Fig. 3 

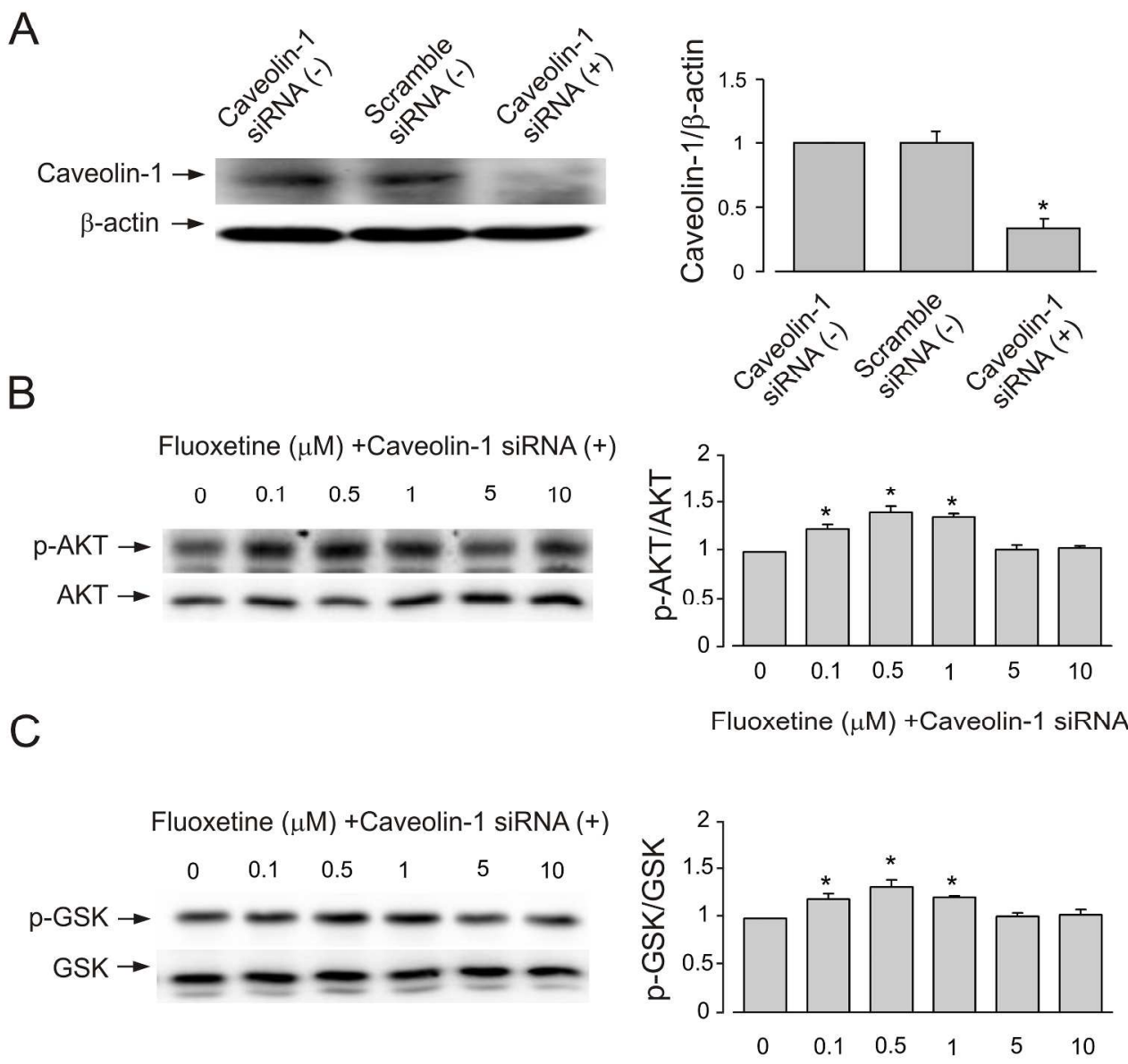

Fluoxetine $(\mu \mathrm{M})+$ Caveolin-1 siRNA (+)

Fig. 4 


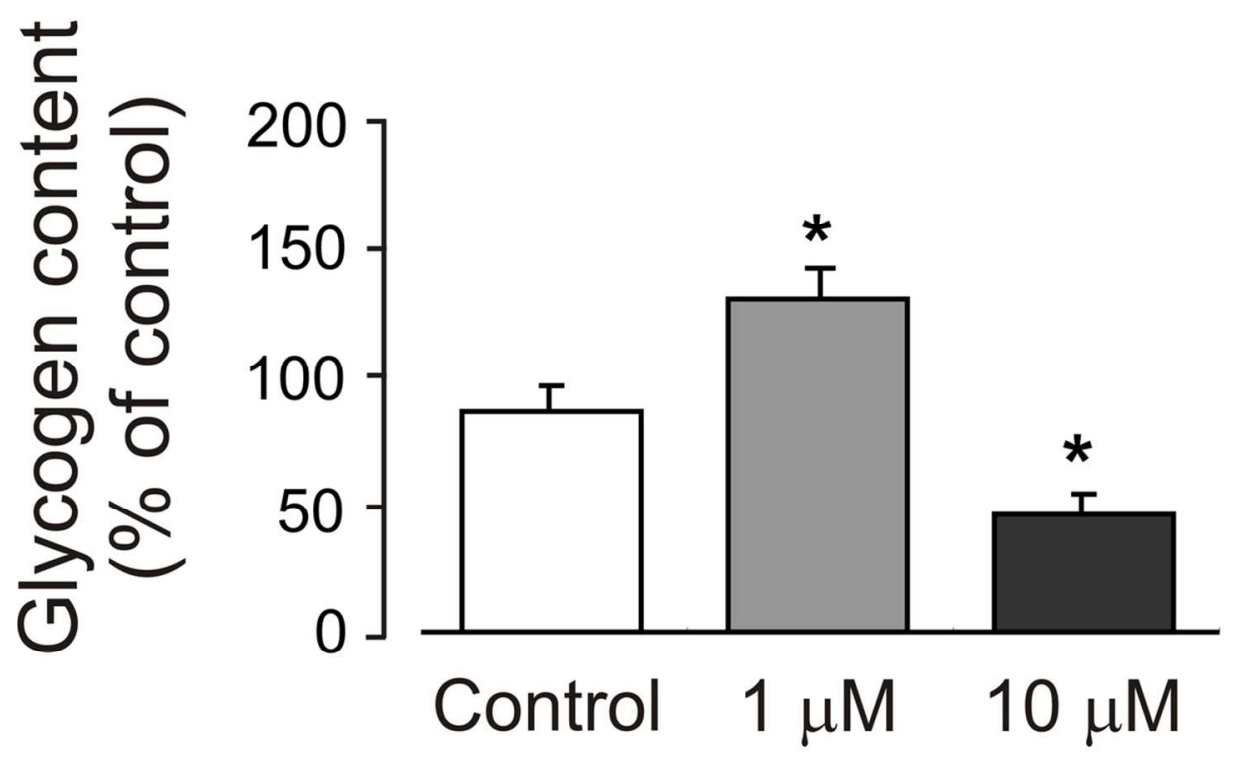

Fluoxetine

Fig. 5 